\title{
Türkiye'de Sağlık Yönetimi Alanında Lisans Eğitimini Sürdürmekte Olan Öğrencilerin Genel Profilinin Belirlenmesine Yönelik Bir Çalışma*
}

\author{
A Profile Study of Bachelor's Degree Health Management Students \\ in Turkey
}

\section{Hatice ULUSOY \\ Nurperihan TOSUN ${ }^{I}$ \\ Jebagl Canberk AYDIN ${ }^{I}$ \\ ${ }^{1}$ Cumhuriyet Üniversitesi, Sağllk Bilimleri Fakültesi, Sağlık Yönetimi Bölümü}

Yazışma adresi/

Coresspondence

Dr.Hatice ULUSOY,

Cumhuriyet Üniversitesi,

Sağllk Bilimleri Fakültesi,

Sağllk Yönetimi Bölümü

hulusoy@cumhuriyet.edu.tr

Geliş Tarihi/Recevied 20/06/2014

Kabul Tarihi/Accepted $28 / 09 / 2014$

HSP 2014 1(2):10-22

\section{Özet}

$\mathrm{Bu}$ çalışmanın amacı Sağlık Yönetimi alanında lisans eğitimini sürdürmekte olan öğrencilerin genel profilini saptamaktır. Tanımlayıcı araştırmanın evrenini, 2012-2013 eğitim-öğretim yllında Türkiye'de bu alanda eğitim veren 28 üniversitedeki tüm öğrenciler $(\mathrm{N}=3692)$ oluşturmuştur. Çalışmada örneklem seçimine gidilmemiş, çalı̧̧maya katılmayı kabul eden okullar örnekleme dahil edilmiştir. Çalışmaya üçü özel olmak üzere, 11 üniversiteden 1624 öğrenci katılmış olup, \% 64,3'ünü kız öğrenciler oluşturmuş̧ur. Yaş ortalaması 21,12'dir. Öğrencilerin \%87,6'sı üniversite sınavına ilk veya ikinci girişlerinde yerleşirken, ilk tercihi sağlık yönetimi olanların oranı $\% 28,9$ 'dur. $\% 50,7$ 'sinin ilk üç tercihi arasında "sağllk yönetimi" bulunmazken, $\% 50,3$ 'ü mümkün olsa bölümü yeniden tercih edeceğini, $\% 50,1$ 'i bölümü kazandığına memnun olduğunu, $\% 23,8$ 'i bölüm değiștirmeyi düşündüğünü belirtmiştir. Mezuniyet sonrasında \%57,6's1 kamuda, $\% 18,5^{\prime}$ i üniversitede çalışmak isterken, $\% 66,9$ 'u lisansüstü eğitim yapmak istemektedir. \%64,2'sinin annesi, \%45,1'inin babası en fazla ilkokul mezunudur, \%54,7'sinin ailesinin aylık geliri 1500TL'den azdır. Türkiye'de sağlık yönetimi alanında öğrenim görmekte olan tüm öğrencilerin \%44'ü çalışmaya katılmış olup, çalışmadan elde edilen verilerin eğitim programlarını şekillendirmede yararlı olacağı düşünülmüştür.

Anahtar Kelimeler: sağlık yönetimi, öğrenci, profil çalışması

\begin{abstract}
Abstrac
The purpose of this study to determine the profile of Bachelor's Degree Health Management Students' in Turkey. In this descriptive study sample consisted of 3692 students from 28 university. A questionnaire, developed by the researchers was mailed to all faculties which accepted to participate into the study. In total 1624 students filled the questionnaire of them 64,3 were female. The mean age was 21,12 . Of the students $87,6 \%$ were entered the university education in their first or second attempt. 50,7\% didn't prefer health management in their first three choices. Half of them were happy with their replacement, 23,8\% were unhappy. Following the graduation, 57,6\% want to work in public sector. In total $66,9 \%$ were planning to study post graduate education. Of the students $64,2 \%$ of the mothers and the $45,1 \%$ of the fathers were graduated from primary school. Monthly incomes of $54,7 \%$ of the families were less than 1500TL. 44\% of all health management students in Turkey participated into the study. It is believed that the findings will be helpful in designing the educational programmes in these departments.
\end{abstract}

Keywords: health management, student, profile study

\footnotetext{
*Bu çalışma 27-29 Eylül 2013 tarihleri arasında Konya'da gerçekleşen 7.Ulusal Sağlık ve Hastane İdaresi
} Kongresinde sözel bildiri olarak sunulmuştur. 


\section{Giriş}

Sağlık yönetimi, yönetim bilimi içinde multidisipliner bir alan olup, bireylerin ve toplumların sağlık düzeylerinin yükseltilmesi amacıyla kaynak ve süreçlerin planlanması, örgütlenmesi, yönlendirilmesi, kontrol ve koordinasyonudur. Sağlık yönetici ise sağlık hizmetlerinin planlanmasını ve amaçlarına uygun olarak, diğer insanlar aracılığıyla süreçlerin yürütülmesini sağlayan profesyoneldir.

Profil araştırmaları, araştırmanın evrenini oluşturan hedef kitlenin mevcut durumunu çeşitli değişkenler açısından betimlemedir. Öğrenci profilini tanımlama çalışması ise, eğitimin belli bir tür ve düzeyinde öğrenim görmekte olan bireylerin herkesçe gözlemlenebilir ortak özelliklerinin olabildiğince nicelleştirilmesi ve istatistiksel olarak ifadesi olarak tanımlanmaktadır. ${ }^{1}$

Öğrenci profilini belirlemeye yönelik çalışmalar; öğrencilerin sosyal, ekonomik ve kültürel yapılarını öğrenmek, akademik ve mesleki olarak beklentilerini ve geleceğe yönelik planlarını saptamak, meslek hakkındaki bazı düşüncelerini ortaya koymak, seçtikleri meslekle geleceğe yönelik beklentilerinin ne ölçüde örtüştüğünü görmek açısından önem taşımaktadır. Bu çalışmalar, öğrencilerin özelliklerinin daha iyi tanınması ve onların özelliklerine göre eğitim kalitesinin artırılmasına yönelik yapılan çalışmalara da ışık tutabilir. ${ }^{2}$

Ülkemizde ilk olarak 1963 yılında başlayan sağlık yönetimi eğitimi, günümüzde giderek artan bir şekilde çok sayıda üniversitede devam etmektedir. Sağlık Yönetimi alanında lisans eğitimini sürdürmekte olan öğrencilerin sosyo- demografik özelliklerinin ve öğrenim gördükleri alana ilişkin bazı düşüncelerinin bilinmesi ve eğitim sürecinde dikkate alınması, verilen eğitimin niteliğinin arttırılması ve mesleğin geleceğini yansıtması açısından önemlidir. Ülke genelinde müfredat çalışmalarının yapılmaya devam ettiği günümüzde, bu çalışmanın sonucundan elde edilecek verilerle, öğrencilerin genel profilini saptamak ve geleceğe yönelik tercihlerini almak mümkün olabilecek, elde edilecek verilerin, müfredatı şekillendirmede, öğrencilerin alt yapısına ve gereksinimlerine uygun olacak derslerin seçiminde, eğitimin yöneticilerine ve öğretim üyelerine 1 şı tutacağı düşünülmektedir.

Ülkemizde genel olarak üniversitelerde ve diğer bazı mesleklerde öğrenci profilini belirlemeye yönelik birçok tanım ve çalışma yapılmış olmasına rağmen sağlık yönetimi alanında okuyan öğrencilerin profilinin saptanmasına yönelik geniş çaplı, bir araştırmaya rastlanmamıştır. $^{1-5} \mathrm{Bu}$ doğrultuda, bu araştırmanın amacı, Sağlık Yönetimi alanında lisans eğitimini sürdürmekte olan öğrencilerin genel profilini saptamaktır. 


\section{Gereç ve Yöntemler}

Tanımlayıcı olarak planlanan araştırmanın evrenini, Türkiye genelinde 2012-2013 eğitim öğretim yılında Sağlık Yönetimi alanında (Sağlık İdaresi, Sağlık Kurumları Yöneticiliği, Sağlık Kurumları İşletmeciliği) lisans düzeyinde eğitim veren tüm $(\mathrm{N}=28)$ fakülte ve yüksekokullarda öğrenim görmekte olan tüm öğrenciler ( $\mathrm{N}=3692)$ oluşturmaktadır. Çalışmada örneklem seçimine gidilmemiştir, anket doldurmayı kabul eden tüm öğrenciler örneklemi oluşturmuştur. Çalışmada, sağlık yönetimi alanında eğitim veren lisans programları ÖSYM'nin 2012 Öğrenci Seçme ve Yerleştirme Sistemi (ÖSYS) Yükseköğretim Programları ve Kontenjanları Kılavuzundan (ÖSYM, 2012) belirlenmiştir. ${ }^{6}$

Bölümlerin yöneticileri (Bölüm Başkanı veya Yüksekokul Müdürü) ile e-posta ve/veya telefonla iletişim kurulmuş, çalışmanın amacı ve yöntem açıklanmış, çalışmaya katılımın gönüllülük ilkesine dayalı olduğu vurgulanmıştır.

Çalışmada veriler araştırmacılarca hazırlanan toplam 36 sorudan oluşan bir anket formu ile toplanmıştır. Çalışmaya katılmayı kabul eden yöneticilerin okullarına anketler kargo ile gönderilmiş, ilgili yöneticinin belirlediği anketör(ler) anketleri öğrencilere uygulamıştır. Araştırmanın amacı, yöntemi ve katılımın gönüllü olduğu bilgisi anketin ilk sayfasında da öğrencilerin dikkatini çekecek şekilde belirtilmiştir.

Mart- Nisan 2013 tarihleri arasında uygulanan anketler bir üniversite hariç tüm üniversitelerde ilgili bölümün öğretim elemanlarınca uygulanmıştır. Bir üniversiteye çalışmanın 2. ve 3. yazarı bizzat giderek anketleri öğrencilere uygulamışlardır.

Cumhuriyet Üniversitesi Bilimsel Araştırma ve Yayın Etiği Yönergesi, madde 5, c fikrasında belirtilen "Sosyal ve beşeri bilimlerde yapılacak anket ve tutum araştırmalarında katılımcıların rızası alınır. Araştırma, bir kurumda yapılacaksa, katılımcıların rızasından sonra bağlı bulundukları kurumun izni alınır" hükmüne dayanarak çalışma için "Etik Kurul” onayı almaya gerek duyulmamıştır. ${ }^{7}$

Toplanan veriler SPSS 14 programı ile sıklık, yüzdelik, ki kare kullanılarak analiz edilmiştir.

Ülkemizde sağlı yönetimi alanında eğitim veren fakülte ve yüksekokullarda bulunan bölümlerin isimleri "sağlık yönetimi, sağlık idaresi, sağlık kurumları yöneticiliği, sağlık kurumları işletmeciliği” gibi farklı isimlere sahiptir. Bu makalede okuyucuya kolaylık olması açısından ve bölümlerin çoğunun adının sağlık yönetimi olmasından dolayı bölüm adı olarak “sağlık yönetimi” terimi kullanılacaktır. 


\section{Öğrencilerin Üniversite ve Fakültesine Göre Dağılımı (N=1624)}

\begin{tabular}{lccc}
\hline & \multicolumn{3}{c}{ Fakülte/YO Adı } \\
Devlet Üniversiteleri $(\mathrm{N}=1425 ; \% 87,7)$ & SBF & SYO & İiBF \\
\hline 1. Süleyman Demirel & & 240 & \\
2. Gümüşhane & & 240 & \\
3. Afyon Kocatepe & 195 & & \\
4. Cumhuriyet & 157 & & 108 \\
5. Selçuk & 115 & & \\
6. Ankara & & & \\
7. Dicle & 89 & & \\
8. İstanbul & & & \\
Özel Üniversiteler (N=199; \%12,3) & 92 & & 389 \\
\hline 9. Medipol & 61 & & 24.0 \\
10. Yeni Yüzyıl & & 46 & \\
11. İstanbul Bilim & 709 & 526 & \\
Toplam & 43,6 & 32,4 & \\
\% &
\end{tabular}

*SBF: Sağlık Bilimleri Fakültesi, SYO: Sağlı Yüksek Okulu, İIBF: İktisadi ve İdari Bilimler Fakültesi

Yukarıda ki tablodan da görülebileceği gibi, çalışmaya üçü özel olmak üzere toplam 11 üniversiteden 1624 öğrenci katılmış olup, Türkiye'de sağlık yönetimi alanında okuyan 3692 öğrencinin \%44'üne ulaşılmıştır. Çalışmaya katılan öğrencilerin \%87,7'sini Devlet Üniversitelerinde okuyanlar oluştururken, \%43,6'sının bağlı olduğu fakülte, Sağlık Bilimleri Fakültesidir (SBF).

\section{Bulgular}

Tablo 1'de görüldüğü gibi öğrencilerin \%42,9'u 21-22 yaş grubunda olup yaş ortalamas1 21,12'dir (18-45). Katılımcıların \% 64,3'ünü kız öğrenciler, 35,7'sini 1. sınıf öğrencileri, 71,3'ünü normal öğretim (NÖ) öğrencileri oluşturmaktadır. Tüm öğrencilerin yalnızca \%1,3’ü üniversiteye girişte ilk 10.000 de bulunmaktadır. \% 46,4'ü üniversiteye gelmeden önce en uzun süre yaşadığı yeri köy/belde/ilçe olarak belirtilmiştir. Doğu ve Güneydoğu Anadolu Bölgeleri her dört öğrenciden birinin (\%25,7) üniversiteye gelmeden önce en uzun süre yaşadığ 1 bölgedir. Öğrencilerin \%43’ünün ilgilendiği bir hobisi, \%26'sının herhangi bir alanda iş deneyimi vardır. 
Tablo 1. Öğrencilerin Tanıtıcı Özellikleri

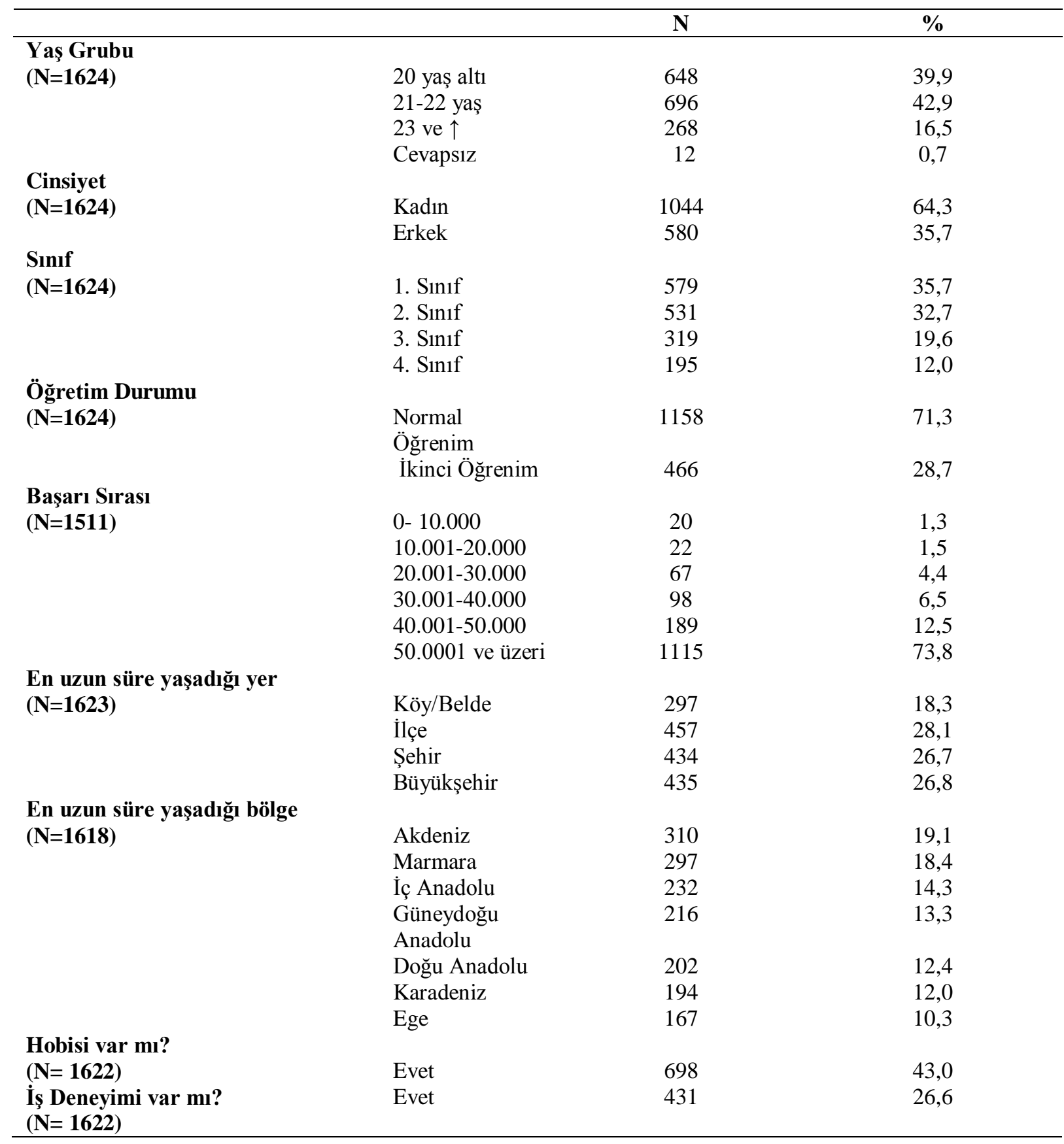

Tablo 2'de çalışmaya katılan öğrencilerin aileleri ile ilgili bazı tanıtıcı özellikler verilmiştir. Buna göre ailelerin \% 27,3'ü köy veya beldede yaşamaktadır. Öğrencilerin annelerinin \%64,2'si babalarının \%45,1'i en fazla ilkokul mezunudur. Annelerin \%86,7'si ev hanımı, babaların \%37,2 si serbest meslek sahibidir. Öğrencilerin \%75,7'sinin aile tipi çekirdek ailedir. Ailelerin \%54,7'sinin aylık geliri 1500 TL ve altındadır. Ailedeki ortalama çocuk sayısı 3,94'tür. 
Tablo 2. Öğrencilerin Ailelerine Ait Özellikler

\begin{tabular}{|c|c|c|}
\hline & $\mathrm{N}$ & $\%$ \\
\hline \multicolumn{3}{|l|}{ Ailenin Yașadığı Yer $(\mathrm{N}=1624)$} \\
\hline Köy/Belde & 443 & 27,3 \\
\hline İlçe & 416 & 25,6 \\
\hline Şehir & 386 & 23,8 \\
\hline Büyükşehir & 379 & 23,3 \\
\hline \multicolumn{3}{|l|}{ Anne Eğitimi (N=1598) } \\
\hline OY Değil & 126 & 7,9 \\
\hline İlkokul & 900 & 56,3 \\
\hline Ortaokul & 226 & 14,1 \\
\hline Lise & 238 & 14,9 \\
\hline Ön lisans & 23 & 1,4 \\
\hline Lisans & 85 & 5,3 \\
\hline \multicolumn{3}{|l|}{ Baba Eğitimi (N=1620) } \\
\hline OY Değil & 42 & 2,6 \\
\hline İlkokul & 689 & 42,5 \\
\hline Ortaokul & 258 & 15,9 \\
\hline Lise & 389 & 24,0 \\
\hline Ön lisans & 61 & 3,8 \\
\hline Lisans & 181 & 11,2 \\
\hline \multicolumn{3}{|l|}{ Anne Mesleği $(\mathrm{N}=1603)$} \\
\hline Ev Hanımı & 1389 & 86,7 \\
\hline İşçi & 60 & 3,7 \\
\hline Memur & 71 & 4,4 \\
\hline Emekli & 50 & 3,1 \\
\hline Diğer & 33 & 2,1 \\
\hline \multicolumn{3}{|l|}{ Baba Mesleği $(N=1568)$} \\
\hline Serbest & 583 & 37,2 \\
\hline Emekli & 286 & 18,2 \\
\hline Memur & 264 & 16,8 \\
\hline İşçi & 201 & 12,8 \\
\hline Çiftçi & 191 & 12,2 \\
\hline İşsiz & 43 & 2,7 \\
\hline \multicolumn{3}{|l|}{ Aile Tipi (N=1622) } \\
\hline Çekirdek & 1228 & 75,7 \\
\hline Geniş & 394 & 24,3 \\
\hline \multicolumn{3}{|l|}{ Gelir Düzeyi (N= 1584) } \\
\hline 1000TL'den Az & 419 & 26,5 \\
\hline 1001-1500TL & 446 & 28,2 \\
\hline 1501-2000TL & 304 & 19,2 \\
\hline 2001-2500TL & 142 & 9,0 \\
\hline 2501-3000TL & 100 & 6,3 \\
\hline 3001 ve üstü & 173 & 10,9 \\
\hline Ailedeki çocuk sayısı ortalaması & 3,94 (Ss: 2,27) & \\
\hline
\end{tabular}

Tablo 3. Öğrencilerin Ailelerinin Gelir Düzeyi İle Çocuk Sayısı Ortalaması

\begin{tabular}{lccc}
\hline Aylık Gelir & N & Ort & Ss \\
\hline 1000TL'den Az & 419 & 4,94 & 2,68 \\
1001-1500TL & 440 & 3,80 & 2,03 \\
$1501-2000 T L$ & 301 & 3,52 & 1,97 \\
$2001-2500$ & 139 & 3,25 & 1,55 \\
$2501-3000$ & 99 & 3,06 & 1,51 \\
3001 ve üstü & 172 & 3,70 & 2,34 \\
Total & 1570 & $\mathbf{3 , 9 4}$ & 2,27 \\
\hline
\end{tabular}

$\mathrm{F}=26,247, \mathrm{p}=0,000$ 
Tablo 3’te Sağlık yönetimi öğrencilerinin ailelerinin gelir düzeyi ve ortalama çocuk sayısı verilmiştir. Ailelerin ortalama çocuk sayısı 3,94’tür. Ailenin gelir düzeyi azaldıkça çocuk sayısı artmaktadır $(\mathrm{p}<0,001)$.

Tablo 4. Öğrencilerin Sağlık Yönetimi Tercihleri ile İlgili Bilgilerin Dağılımı

\begin{tabular}{|c|c|c|}
\hline & $\mathbf{N}$ & $\%$ \\
\hline \multicolumn{3}{|c|}{ Üniversite Sınavına Giriş Sayısı (N=1599) } \\
\hline 1. Giriş & 729 & 45,6 \\
\hline 2. Giriş & 671 & 42,0 \\
\hline 3. Giriş & 150 & 9,4 \\
\hline 4 ve üzeri & 49 & 3,1 \\
\hline \multicolumn{3}{|l|}{ Tercih Sirası $(N=1586)$} \\
\hline 1. Tercih S. Yönetimi & 459 & 28,9 \\
\hline 2. Tercih S. Yönetimi & 155 & 9,8 \\
\hline 3. Tercih S. Yönetimi & 168 & 10,6 \\
\hline İlk 3 de S. Yönetimi Yok & 804 & 50,7 \\
\hline \multicolumn{3}{|c|}{ Bölümü Tekrar Seçer misiniz? (N=1609) } \\
\hline Evet & 810 & 50,3 \\
\hline Hayır & 799 & 49,7 \\
\hline \multicolumn{3}{|c|}{ Yeniden Üniv. Sınavına Girerek Bölüm Değiștirmeyi Düşünme (N=1621) } \\
\hline Evet & 385 & 23,8 \\
\hline Hayır & 1236 & 76,2 \\
\hline \multicolumn{3}{|c|}{$\begin{array}{l}\text { Bölümü Kazanmış Olmaktan Memnuniyet }(\mathrm{N}=1623) \\
\text { ( Ort: } 3,38 \text { / Ss 1,03) }\end{array}$} \\
\hline 1. Kesinlikle Memnun Değil & 94 & 5,8 \\
\hline 2. Memnun Değil & 203 & 12,5 \\
\hline 3. Kararsız & 513 & 31,6 \\
\hline 4. Memnun & 615 & 37,9 \\
\hline 5. Çok Memnun & 198 & 12,2 \\
\hline \multicolumn{3}{|c|}{$\begin{array}{l}\text { Şu anda S. Yönetimi Öğrencisi Olmaktan Memnuniyet }(\mathrm{N}=1624) \\
\text { (Ort: } 3,34 \text { / Ss 1,03) }\end{array}$} \\
\hline 1. Kesinlikle Memnun Değil & 96 & 5,9 \\
\hline 2. Memnun Değil & 220 & 13,5 \\
\hline 3. Kararsiz & 513 & 31,6 \\
\hline 4. Memnun & 621 & 38,2 \\
\hline 5. Çok Memnun & 174 & 10,7 \\
\hline
\end{tabular}

Öğrencilerin \%87,6's1 ilk veya 2. girişlerinde programa yerleşirken, ilk tercihi sağlık yönetimi olanların oranı \%28,9'dur. Öğrencilerin \%50,7'sinin ilk 3 tercihi arasında sağlık yönetimi bölümü bulunmazken, \%50,3’ü mümkün olsa bölümü yeniden tercih edeceğini belirtmiştir. \%76,2'si bölüm değiştirmeyi düşünmediğini, \%50,1'i sağl1k yönetimi bölümünü kazanmış olmaktan, \%48,9’u şu anda sağlık yönetimi öğrencisi olmaktan memnun/çok memnun olduğunu belirtmiştir (Tablo 4). 
Tablo 5. Öğrencilerin Üniversitenin Statüsüne Göre Bölümü Kazanmış Olmaktan ve Bölümün Öğrencisi Olmaktan Duydukları Memnuniyet Düzeyi

\begin{tabular}{lcc}
\hline & $\begin{array}{c}\text { Bölümü Kazanmış Olmaktan } \\
\text { Memnuniyet }\end{array}$ & $\begin{array}{c}\text { Şu anda S. Yön. } \\
\text { Öğrencisi Olmaktan Memnuniyet }\end{array}$ \\
\hline $\begin{array}{l}\text { Devlet Üniversiteleri } \\
\mathrm{N}=1424\end{array}$ & $3,33 \pm 1,04$ & $3,29 \pm 1,04$ \\
Özel Üniversiteler & $3,70 \pm 0,93$ & $3,71 \pm 0,85$ \\
$\mathrm{~N}=199$ & $3,38 \pm 1,03$ & \\
Toplam & & $3,34 \pm 1,03$ \\
$\mathrm{~N}=1623$ & F 22,72 & $\mathrm{~F} 30,56$ \\
& p: 0,000 & p: 0,000 \\
\hline
\end{tabular}

Öğrencilere 5'li likert tipinde iki soru ile bu bölümü kazanmış olmaktan ve bölümün öğrencisi olmaktan duydukları memnuniyet düzeyi sorulduğunda alınan yanıtların puan ortalamaları tablo 5 de görülmektedir. Buna göre devlet üniversitelerinin öğrencilerinin okuduğu bölümü kazanmış olmaktan memnuniyet ortalaması 3,33 $\pm 1,04$ iken, özel üniversitelerin

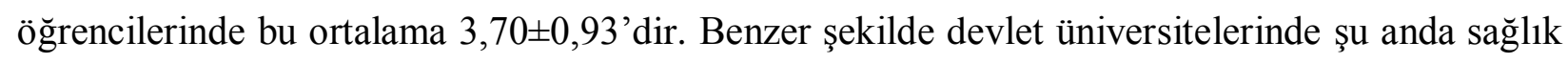

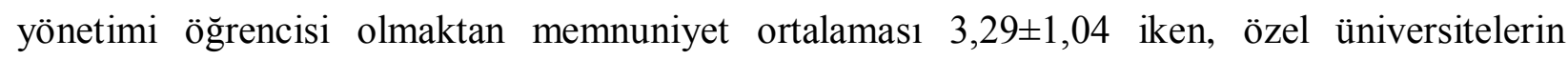
öğrencilerinde bu ortalama 3,71 $\pm 0,85$ 'dir. Fark istatistiksel olarak anlamlıdır $(\mathrm{p}<0,000)$ (Tablo $5)$.

Tablo 6. Öğrencilerin Üniversitelerine Göre İlk Üç Tercihlerinde Sağlık Yönetimi Bölümünü Tercih Etmelerine Göre Dağılımı

\begin{tabular}{lcc}
\hline Üniversite Adı & $\begin{array}{c}\text { Birinci Tercih } \\
\text { Sağlik Yönetimi } \\
\%\end{array}$ & İlk 3 de Sağlik Yön. Yok \\
\hline Medipol & 53,4 & 22,7 \\
Yeni Yüzyll & 47,4 & 31,6 \\
İstanbul Bilim & 34,8 & 43,5 \\
Afyon Kocatepe & 30,2 & 51,5 \\
Gümüşhane & 28,9 & 52,2 \\
İstanbul & 28,1 & 59,6 \\
Süleyman Demirel & 27,8 & 44,4 \\
Dicle & 24,5 & 51,9 \\
Selçuk & 23,9 & 55,5 \\
Cumhuriyet & 22,6 & 63,1 \\
Ankara & 21,2 & 59,3 \\
Total & $\mathbf{2 8 , 9}$ & $\mathbf{5 0 , 7}$ \\
\hline
\end{tabular}

Tablo 6'da öğrencilerin üniversitelerine göre ilk üç tercihlerinde sağlı yönetimi bölümünü tercih etmelerinin dağılımı verilmiştir. Buna göre Medipol Üniversitesi öğrencilerinin 
\%53,4'ü ve Yeni Yüzyıl Üniversitesi öğrencilerinin yaklaşık yarısı üniversiteye giriş sınavlarında sağlık yönetimini ilk tercih olarak yazdıklarını belirtmişlerdir. Cumhuriyet Üniversitesi öğrencilerinin \%63,1'i, ilk 3 tercihleri arasında sağlı yönetiminin yer almadığını belirtmiştir.

Tablo 7. Üniversitelere Göre Öğrencilerin “İmkanınız Olsa Bölümü Tekrar Seçer miydiniz?" Sorusuna Yanıtlarının Dağılımları

\begin{tabular}{lcc}
\hline Üniversite Adı & $\begin{array}{c}\text { Evet } \\
\text { \% }\end{array}$ & $\begin{array}{c}\text { Hayır } \\
\mathbf{\%}\end{array}$ \\
\hline İstanbul Bilim & 68,9 & 31,1 \\
Yeni Yüzyıl & 68,3 & 31,7 \\
İstanbul & 67,0 & 33,0 \\
Medipol & 65,9 & 34,1 \\
Dicle & 56,5 & 43,5 \\
Gümüşhane & 58,5 & 41,5 \\
Süleyman Demirel & 52,7 & 47,3 \\
Cumhuriyet & 45,1 & 54,9 \\
Selçuk & 40,6 & 59,4 \\
Afyon Kocatepe & 35,0 & 65,0 \\
Ankara & 33,9 & 66,1 \\
Total & $\mathbf{5 0 , 3}$ & $\mathbf{4 9 , 7}$ \\
\hline
\end{tabular}

Tablo 7'de görüldüğü gibi tüm öğrencilerin yaklaşık yarısı $(\% 50,3)$ bölümü tekrar seçeceğini belirtirken, Bilim, Yeni Yüzyıl ve İstanbul Üniversitesi öğrencilerinin çoğunluğu (surasıyla, \%68,9; \%68,3; \%67) yeniden tercih yapmak gerekseydi bu bölümü tekrar seçebileceğini ifade etmişlerdir.

Tablo 8. Öğrencilerin Gelecekte Çalışmayı İstediği Alanların Dağılımı $(N=1624) *$

\begin{tabular}{lcc}
\hline & $\mathbf{N}$ & $\mathbf{\%}$ \\
\hline Devlet Hastanesi & 755 & 46,4 \\
Özel Hastaneler & 687 & 42,3 \\
Bakanlıklar & 349 & 21,4 \\
Üniversite Hastanesi & 300 & 18,5 \\
Akademisyenlik & 298 & 18,3 \\
İlaç sektörü & 171 & 10,5 \\
Sağlık sigortacılı̆̆ & 129 & 7,9 \\
\hline Diğger & 41 & 2,5
\end{tabular}

* Öğrencilerin yanıtları birden fazladır

Tablo 8'de görüldüğü gibi öğrencilerin \%46,4'ü Devlet Hastanelerinde, \%42,3'ü Özel hastanelerde çalışmayı planlamaktadır. Bakanlıklar, Üniversite hastaneleri ve akademisyenlik de 
öğrencilerin planlamaları arasındadır. Öğrencilerin \%10,5’i İlaç sektöründe, \%7,9’u ise sağlık sigortacılığı sektöründe çalışmayı planlamaktadır.

Tablo 9. Öğrencilerin Üniversitelerine Göre Gelecekte Çalışmak İsteği Sektöre Göre Dağılımı

\begin{tabular}{lcc}
\hline & \multicolumn{2}{c}{$\begin{array}{c}\text { Gelecekte hangi sektörde çalışmayı istiyorsunuz? } \\
(\mathbf{N = 1 6 2 4 )}\end{array}$} \\
\hline & KAMU & ÖZEL \\
Cumhuriyet & $\%$ & $\%$ \\
Afyon Kocatepe & $\mathbf{7 0 , 3}$ & 29,7 \\
Gümüşhane & 70,2 & 29,8 \\
Süleyman Demirel & 68,9 & 31,1 \\
Selçuk & 59,1 & 40,9 \\
Dicle & 58,6 & 41,4 \\
Ankara & 58,3 & 41,7 \\
İstanbul & 51,3 & 48,7 \\
Bilim & 44,3 & 55,7 \\
Medipol & 26,1 & 73,9 \\
Yeni yüzy11 & 21,7 & 78,3 \\
& 21,3 & 78,7 \\
TOPLAM & & \\
& $\mathbf{5 7 , 6}$ & 42,4 \\
\hline
\end{tabular}

Çalışmaya katılan öğrencilerin \%57,6'sı gelecekte kamuda; Cumhuriyet, Afyon ve Gümüşhane Üniversitelerinin öğrencilerinin büyük çoğunluğu kamuda, özel üniversite öğrencilerinin çoğunluğu özel sektörde çalışmayı planlamaktadır (Tablo 9).

Tablo 10.Üniversitelere Göre Lisansüstü Eğitim Yapma İsteklerinin Dağılımı

Lisansüstü eğitime (master/doktora) devam etmek istiyor musunuz?

$(\mathrm{N}=1623)$

\begin{tabular}{lcc}
\hline & EVET & HAYIR \\
Bilim & $\%$ & $\%$ \\
Yeni yüzyıl & 93,5 & 6,5 \\
Medipol & 85,2 & 14,8 \\
İstanbul & 82,6 & 17,4 \\
Ankara & 77,5 & 22,5 \\
Dicle & 73,9 & 26,1 \\
Afyon Kocatepe & 69,4 & 30,6 \\
Gümüşhane & 66,7 & 33,3 \\
Süleyman Demirel & 64,6 & 35,4 \\
Cumhuriyet & 61,2 & 38,8 \\
Selçuk & 57,2 & 42,8 \\
\hline TOPLAM & 55,4 & 44,6 \\
\hline
\end{tabular}


Üniversitelere göre öğrencilerin lisansüstü eğitim yapma istekleri incelendiğinde Özel üniversite öğrencilerinin çok büyük çoğunluğunun, toplamda öğrencilerin \%66,9'unun lisansüstü eğitim yapmak istediği saptanmıştır.

\section{Tartışma ve Sonuç}

Toplam 11 üniversiteden sağlık yönetimi alanında öğrenim gören 1624 öğrencinin katıldığı bu çalışmada bölümün daha çok kız öğrenciler (\% 64,3) tarafından tercih edildiği saptanmıştır. Çalışma kapsamına alınan üniversitelerin bazılarının eğitime yeni başlamış olması nedeniyle, çalışmaya katılan öğrencilerin çoğunluğunu 1. ve 2. sinıflar oluşturmuştur. Üniversite öğrenci kontenjanlarının da artırılmasıyla birlikte özellikle gelecekteki 3-4 yıl içinde mezun sayısında önemli bir artışın yaşanacağı bu mezunların istihdamının ve sağlık yöneticisi yetiştiren kurumların öğretim elemanı ve diğer koşullarının ilgililerce dikkate alınması gerektiğ söylenebilir. ${ }^{8}$

Çalışmamızda öğrencilerin annelerinin \%64,2'si, babalarının \%45,1'i en fazla ilkokul mezunudur. Annelerin \%5,3'ü, babaların \%11,2'si lisans derecesine sahiptir. Tanalp ve arkadaşlarının (2012) 229 diş hekimliği fakültesi öğrencisi ile yaptığı çalışmasında, annelerin \%56's1, babaların \%72'si lisans ve üzeri (yüksek lisans- doktora) dereceye sahiptir. Yiğit ve arkadaşlarının (2007) 21 üniversitede, hemşirelik son sınıfta okuyan 1009 öğrenci ile yaptığı çalışmada annelerin \%80'i, babaların \%48'i en fazla ilkokul mezunudur. ${ }^{4-9}$ Kostak ve arkadaşlarının (2012) 276 hemşirelik ve ebelik öğrencisi ile yaptı̆̆ çalışmada ise annelerin $\% 67$ 'si, babalarının \%45'i en fazla ilkokul mezunudur. ${ }^{5} \mathrm{Bu}$ bulgulara dayanarak çalışmamıza katılan öğrencilerin anne-baba eğitimlerinin hemşirelik ebelik öğrencileri ile benzer olduğunu, diş hekimliği öğrencilerinin anne-baba eğitimlerinin ise oldukça yüksek düzeyde olduğunu söyleyebiliriz.

Çalışmamızda annelerin 86,7'si ev hanımı, babaların 37,2'si serbest meslek sahibidir. Ailelerin \%54,7'sinin aylık geliri 1500 TL ve altındadır. Ailedeki ortalama çocuk sayısı 3,94 tür. Anne ve baba mesleği açısından üniversite öğrencileriyle yapılmış diğer bazı çalışmaların bulguları, çalışmamızın bulguları ile paraleldir. ${ }^{3,4,5-10}$ Bulgularımıza dayanarak öğrencilerin büyük çoğunluğunun ailelerinin sosyo-ekonomik düzeyinin düşük olduğunu söyleyebiliriz. Bu nedenle, öğrencilerin üniversite eğitimleri süresince özellikle ekonomik, sosyal, sanatsal alanlarda da desteklenmelerini önerebiliriz.

Öğrencilerin çok büyük bir çoğunluğu $(\% 87,6)$ sağlik yönetimi bölümlerine ilk veya 2. girişlerinde yerleşmiş olup, sağlık yönetimi \%28,9'unun ilk tercihidir, \%49,3'ünün ilk üç 
tercihinde sağlık yönetimi bölümü vardır. Öğrencilerin yaklaşık yarısı bölümü yeniden tercih edebileceğini ifade etmiştir. Bu bulgulara dayanarak öğrencilerin yarısının bölüme bilinçli olarak geldiğini memnuniyet düzeyinin de buna paralel olduğunu söyleyebiliriz. Tanalp ve arkadaşlarının (2012) çalışmasında öğrencilerin \%58,5'i ilk tercih olarak diş hekimliğini yazmıştır. Kostak ve arkadaşlarının (2012) yaptığı çalışmada ise hemşirelik ve ebelik \%26,8'inin ilk 5 tercihi arasındadır. ${ }^{9-5}$

Çalışmada öğrencilerin \%50,1'i sağlık yönetimi bölümünü kazanmış olmaktan, \%48,9’u şu anda sağl1k yönetimi öğrencisi olmaktan memnun olduğunu belirtmiştir. Öğrenci memnuniyeti ile ilgili yapılan bazı çalışmalarda örneğin Aydın Adnan Menderes Üniversitesinde okuyan öğrencilerin ( $\mathrm{N}=344) \% 17,2$ 'sinin oldukça memnun olduğu saptanmıştır. 2012 yılı Cumhuriyet Üniversitesi Öğrenci Memnuniyet Anketi sonuçlarına göre ise üniversite genelinde öğrencilerin \%38,8'i, Sağlık Bilimleri Fakültesi öğrencilerinin ise \% 20,6's1 memnun olduğunu belirtmiştir. Ulusoy ve Karabulut'un (2011) Cumhuriyet Üniversitesi Sağlı Yönetimi Bölümünde öğrenim gören 69 öğrenci ile yaptıkları memnuniyet çalışmasında ise öğrencilerin memnuniyet ortalaması 242,28 $\pm 44,57$ (5 puan üzerinden 3,41) olarak saptanmıştır. Yine Ulusoy ve arkadaşlarının (2010) 223 hemşirelik öğrencisi ile yaptığı çalışmada ise memnuniyet ortalaması 202,78 $\pm 59,33$ olarak saptanmıştır. Bu bulgulara göre sağlık yönetimi öğrencilerinin memnuniyet düzeyinin hemşirelik öğrencilerinden daha yüksek olduğunu söyleyebiliriz. ${ }^{11,12-13}$

Çalışmamızda özel üniversitelerin öğrencilerinin okuduğu bölümü kazanmış olmaktan ve şu anda sağlık yönetimi öğrencisi olmaktan memnuniyet düzeyi devlet üniversitelerine göre anlamlı derecede daha yüksektir. Benzer şekilde özel üniversiteleri ilk tercihleri arasında yazan ve bölümü yeniden tercih edebileceğini söyleyen öğrencilerin oranı da yüksektir. Özel üniversitelerin, öğrencilerine sağladığı sosyal, kültürel ve ekonomik desteklerin fazla olmasının, olanaklarının daha gelişmiş olmasının öğrenci memnuniyetini artırdığı düşünülebilir.

Öğrencilerin kariyer planlamalarıyla ilgili veriler değerlendirildiğinde özel üniversite öğrencilerinin daha çok özel sektörde, devlet üniversitelerinin öğrencilerinin daha çok kamuda çalışmak istediği saptanmıştır. Bu bulguya dayanarak devlet üniversitesindeki öğrencilerin daha çok iş garantisi olduğu düşüncesiyle kamu sektörünü tercih ettikleri düşünülebilir. Oysa ülkemizde sağlık hizmetleri içinde özel sektörün hızla gelişiyor olması nedeniyle mezunların özel sektörde iş bulma imkanlarının daha fazla olabileceği düşünülebilir. O nedenle öğrencilerin özel sektörü daha fazla tanıyabileceği imkanların (staj vb.) sağlanmasını önerebiliriz.

Çalışmaya katılan öğrencilerin büyük çoğunluğunun $(\% 66,9)$ lisansüstü eğitim yapmak istemesinin nedeni, yüksek lisans, doktora mezunlarının iş bulma imkanlarının daha fazla olduğunu düşünmeleri ve öğrencilerin eğitime değer vermeleri olabilir. 
Sonuç olarak Türkiye'de sağlık yönetimi alanında öğrenim görmekte olan tüm öğrencilerin \%44'ünün çalışmaya katılmış olduğu dikkate alındığında, çalışmadan elde edilen verilerin bölümlere eğitim programlarını şekillendirmede yararlı olacağı düşünülmüştür.

\section{Kaynaklar}

1. Özsoy S. Üniversite Öğrenci Profili: Kavramsal Bir Çözümleme ve Türkiye’ye İlişkin Bazı Ampirik Bulgular. Kuram ve Uygulamada Eğitim Bilimleri, 2004; 4:2 301-334.Erişim Adresi: https://www.edam.com.tr/kuyeb/pdf/tr/95228db158c25e69bf981e7ae46aa25dseckin.PDF

2. Sandal EK, Karademir N. Kahramanmaraş Sütçü İmam Üniversitesi Fen Edebiyat Fakültesi Coğrafya Bölümü Öğrencilerinin Profili, Beklenti ve Sorunlarının Değerlendirilmesi. KSÜ Sosyal Bilimler Dergisi, 2013; 10:2. Erişim Adresi: http://sbd.ksu.edu.tr/Imagesimages/files/10_2_08_fen_edebiyat_fakultesi.pdf

3. Özdemir C, Demiriz G. Adnan Menderes Üniversitesi Öğrenci Profili Araştırması 2003, Aydın, 2007.

4. Yiğit R, Esenay F, Derebent E. Türkiye'de Hemşirelik Son Sınıf Öğrencilerinin Profili. Cumhuriyet Üniversitesi HYO Dergisi, 2007; 11(3), 1-12.

5. Kostak M, Akarsu Ö, Ergül G. D. Edirne Sağlık Yüksekokulu Öğrencilerinin Profili. Fırat Sağlık Hizmetleri Dergisi, 2012; 7(19): 39-59.

6. Türkiye Cumhuriyeti Ölçme, Seçme ve Yerleştirme Merkezi (ÖSYM) (2012). Erişim Adresi http://dokuman.osym.gov.tr/pdfdokuman/2012/OSYS/2012OSYSKONTKILAVUZ.pdf

7. Cumhuriyet Üniversitesi (2013). Cumhuriyet Üniversitesi Bilimsel Araştırma ve Yayın Etiği Yönergesi. Erişim

Adresi:http://www.cumhuriyet.edu.tr/yonetmelik/yonergecumhuriyet_universitesi_bilimsel_arastirm a_ve_yayin_etigi_yonergesiturk.pdf

8. Şener E, Erdem R, Akçakanat T. Türkiye'de Lisans Düzeyinde Sağlık Yöneticisi Yetiştiren Kurumların Akademik ve Eğitsel Profili. Hacettepe Sağlık İdaresi Dergisi, 2010; 13:1 29-44.

9. Tanalp J, Dilhan I, Dikbas İ, Oktay İ. Demographic Profile and Future Expectations of Students Enrolled in a Turkish Private Dental School. Journal of Dental Education, 2012; 76:6, 800-809.

10. Tektaş N, Tektaş M, Polat Z, Topuz A.S. Comparing The Expectations Of Undergraduate And Graduate Degree Students .Procedia Social and Behavioral Sciences, 2010; 2 1244-1248.

11. Cumhuriyet Üniversitesi (2012). Cumhuriyet Üniversitesi Öğrenci Memnuniyet Anketi Sonuçları. Erişim Adresi http://www.cumhuriyet.edu.tr/kurumsal_degerlendirme_pdf/Ek7_2012.pdf

12. Ulusoy H, Karabulut N. Sağllk Yönetimi Bölümü Öğrencilerinin Memnuniyet Düzeyleri. 9. Ulusal Sağlık Kuruluşları Yönetimi Kongresi Bildiri Kitabı s. 169-174. 26-29 Mayıs 2011 KKTC

13. Ulusoy H, Arslan Ç, Öztürk N, Bekar M. Hemşirelik Öğrencilerinin Eğitimleriyle İlgili Memnuniyet Düzeylerinin Saptanması. Maltepe Üniversitesi Hemşirelik Bilim ve Sanatı Dergisi, 20103; (2) 1524. 